\title{
Maritime Spatial Planning Supported By Infrastructure for Spatial Information in Europe (INSPIRE)
}

\author{
Andrej Abramic \\ University Las Palmas de Gran Canaria, \\ Emanuele Bigagli \\ Wageningen University \\ Vittorio Barale \\ Directorate D Sustainable Resources, Joint Research Centre, European Commission, Ispra, Italy
}

See next page for additional authors

Follow this and additional works at: https://arrow.tudublin.ie/beschspart

Part of the Other Engineering Commons

\section{Recommended Citation}

Abramic, A., Bigagli, E., Barale, V., Assouline, M., Lorenzo-Alonso, A. \& Norton, C. (2018). Maritime spatial planning supported by infrastructure for spatialinformation in Europe (INSPIRE). Ocean and Coastal Management, 152 (2018), pp.23-36. doi:10.1016/j.ocecoaman.2017.11.007

This Article is brought to you for free and open access by the School of Transport Engineering, Environment and Planning at ARROW@TU Dublin. It has been accepted for inclusion in Articles by an authorized administrator of ARROW@TU Dublin. For more information, please contact arrow.admin@tudublin.ie, aisling.coyne@tudublin.ie,gerard.connolly@tudublin.ie. 


\section{Authors}

Andrej Abramic, Emanuele Bigagli, Vittorio Barale, Alberto Lorenzo-Alonso, and Conor Norton 


\title{
Maritime Spatial Planning supported by Infrastructure for Spatial Information in Europe (INSPIRE)
}

\author{
Andrej Abramic ${ }^{a, *}$, Emanuele Bigagli ${ }^{b}$, Vittorio Barale ${ }^{c}$, Michael Assouline ${ }^{c, d}$, \\ Alberto Lorenzo-Alonso ${ }^{\mathrm{c}, \mathrm{e}}$, Conor Norton ${ }^{\dagger}$
}
a. EcoAqua Institute @ University Las Palmas de Gran Canaria, Scientific \& Technological Marine Park, Taliarte, 35200, Spain
b. Wageningen University, Laboratory of Geo-Information Science and Remote Sensing, Droevendaalsesteeg 3, 6708 PB, Wageningen, The Netherlands
c. Directorate D Sustainable Resources, Joint Research Centre, European Commission, Ispra, Italy
d. European Environment Agency, Copenhagen, Denmark
e. Earth Observation Applications, Indra Sistemas, Madrid, Spain
f. School of Transport Engineering, Environment and Planning, Dublin Institute of Technology, Bolton Street, D01 K822, Ireland

Keywords: Maritime Spatial Planning, Marine Spatial Planning, INSPIRE, Spatial Data Infrastructure, data model, data availability, E-reporting.

\section{Highlights:}

- INSPIRE is a relevant instrument for increasing transparency of MSP processes;

- The INSPIRE data model is adequate for mapping maritime activities; and

- The INSPIRE data model supports integration of sea and land planning.

\begin{abstract}
The implementation of Directive 2007/2/EC - INSPIRE can improve and actually strengthen the information management and data infrastructures needed for setting up Maritime Spatial Planning (MSP) processes. Evidence for this comes from three parallel
\end{abstract}


analyses: links between the MSP Framework Directive and INSPIRE components and implementation; the availability of marine and maritime data through the INSPIRE GeoPortal; and the adequacy of using an INSPIRE data model for mapping maritime spatial plans. The first item identifies INSPIRE as a relevant instrument not only for data collection, but additionally for increasing transparency of the MSP processes, using already operational national and European data infrastructure. The marine/maritime data availability analysis highlights a significant difference in data sharing within European marine regions. Finally, the INSPIRE data model is adequate for mapping maritime activities and for the integration of sea and land planning in an overview of cross-border planning for a given sea region.

Please check Appendix 2 for definitions of the terminology used. 


\section{Introduction}

Ancient sea maps have been traditionally populated by giant serpents and octopuses wrapped around ships, fierce-toothed animals clashing in the waves, deceivingly beautiful mermaids and a variety of other chimeric beings ${ }^{1}$. European map makers used such monstrosities to enchant viewers, but also to educate them about the dangers of the marine environment, dangers that could obstruct maritime activities like shipping, fishing or traveling. Sea monsters were not just mere playful illustrations, they were symbols trying to describe the main traits of a bizarre territory, made of a treacherous liquid element, and difficult to chart because of its featureless, and yet dynamic nature (Ellis, 1994).

Sea monsters started to disappear from maritime maps at the end of the 17th century. As European understanding of the oceans and navigation advanced, more emphasis was placed on the ability of people to master the watery element, to sail on it and conduct trade on it. Illustrations still appeared on maps, but for more pragmatic reasons: drawings of ships indicated areas of safe passage, while whales or other creatures pointed to good fishing areas (Bagrow, 2010). Some of the mystery was now gone and the sea was becoming yet another cradle of natural resources, rather than a churning darkness to be feared. However, the sense of awe captured in the old maps lingers on to this very day, as many dangers and obstacles to maritime endeavours are still with us.

Modern maps of marine regions are free of sea monsters, but do point to a set of problems which are difficult to solve. Today, the main obstacle to human activities at sea is primarily competition for maritime space. Moreover, an increasing hunger for the many resources still available in the sea is placing a heavy burden on the preservation of the marine ecological balance. A management effort is required (IOC, 2006; Ardron et al., 2008; Day, 2008; Douvere and Ehler, 2009; EC, 2010) to avoid potential conflicts and create synergies between different activities (Suarez et al. 2011, Brennan et al., 2014), while at the same time maintaining the ecological resilience of marine complex environmental and social systems (Bigagli, 2015). In order to ease this problem, the concept of Maritime Spatial Planning (MSP) has emerged in recent years, with the aim of coordinating diverse sectors such as energy, transport, fisheries, aquaculture, tourism and environmental

${ }^{1}$ See e.g. Olaus Magnus, Carta marina et Descriptio septemtrionalium terrarum ac mirabilium rerum in eis contentarum, diligentissime elaborata Annon Domini 1539 Veneciis liberal itate Reverendissimi Domini leronimi Quirini, published in Venezia (Venice?), 1539. 
protection. MSP is seen as a process to dictate "...when and where human activities take place at sea" (Dubois et al., 2015; Pranzini et al., 2015) and to ensure that such activities are as efficient and sustainable as possible. Moreover, this process is supposed to involve all persons or groups that have an interest in it, i.e. the stakeholders, in a transparent way, as a public process of analysing and allocating spatial and temporal distribution of human activities in marine areas, in order to achieve economic, social and ecological objectives specified through a political process (Ehler and Douvere, 2009). In the last decade, MSP has gained considerable importance all over the world as a practical tool to avoid conflicts of use between sectors of human activity, and a way of balancing the objectives of environmental protection, economic growth, and social inclusiveness and justice (Ardron et al., 2008; Douvere and Ehler, 2009; Schaefer and Barale, 2011).

MSP made its official appearance on the European Union (EU) legal stage in July 2014, when the European Parliament and the Council adopted legislation to create a common framework for MSP in Europe, i.e. Directive 2014/89/EU (EU, 2014). According to the MSP Directive, each EU Member State (MS) will be free to plan its own maritime space, whereas regional planning in shared basins will have to be harmonised through a set of common requirements. The expected benefits of such a coordinated MSP approach, instilling predictability and transparency in the whole process, will be to reduce conflicts, to encourage investments, to increase cooperation between administrations in each country and between countries sharing the same basin and, ultimately, to help to protect the marine environment through the assessment of challenges and opportunities for multiple use of sea space.

The road to adopting the MSP Directive has been long and complex. Following the establishment of an European Commission (EC) Inter-Service Group on this topic, led by the EC Directorate General for Maritime Affairs and Fisheries (DG MARE), and the publication of a Roadmap on MSP (EC, 2008), to achieve common principles in the EU, a series of four international stakeholders workshops was held in 2009 (Schaefer and Barale, 2011). This led to the release in 2010 of an EC Communication on MSP Achievements and Future Perspectives $(E C, 2010)$ and to a Proposal for a Directive on MSP, combined with Integrated Coastal Management (ICM) elements ${ }^{2}$ (EC, 2013a). This Proposal for a combined MSP and ICM Directive, which was accompanied by related documents on stakeholder consultation and impact assessment (EC, 2013b), later

${ }^{2} \mathrm{ICM}$ is a process for the management of the coastal zone using an integrated approach, including all environmental, economic and political aspects, in an attempt to achieve sustainability. The EC Proposal for a combined MSP and ICM Directive aimed at ensuring a holistic approach to managing the sea and its boundaries. 
evolved into the 2014 Directive mentioned above, focusing only on a European MSP framework (as ICM issues were considered to be exclusively a national concern). Throughout the period during which MSP was maturing in the EU context, various pilot projects on maritime space mapping were conducted by individual EU Member States (MS) and/or sponsored by the EC as international cooperation initiatives (MESMA, 2009; Adriplan, 2012; BaltSeaPlan, 2012a; Stelzenmüller et al., 2013; TPEA, 2014).

A first strand of initiatives took place in the framework of the EU Strategy for the Baltic Region (EC, 2009; EC, 2009b; Bengtsson 2009), where a coordinated and cooperative approach was implemented, based on transnational cooperation structures and a series of research projects (Zaucha, 2014a). The intergovernmental co-operation of 11 Baltic countries into a framework of "Vision and Strategies in Baltic Sea" (VASAB) initiated the process by issuing the so-called Wismar declaration in 2001 (VASAB, 2001), the first official document identifying issues related to the transnational spatial planning in the Baltic Sea region (Zaucha, 2014). Several pilot projects have since followed, contributing to the implementation of a joint MSP approach in an interlinked process. The BaltSeaPlan (2009-2012) and Plan Bothnia (2010-2012) projects implemented practical approaches to MSP in several pilot areas, testing the Intergovernmental Oceanographic Commission (IOC) practical guide to the planning process (Ehler and Douvere, 2009). As stated in the final reports of Plan Bothnia and BaltSeaPlan, a practical approach helped to understand the need to address the transnational data issue (Backer and Frias, 2013; SchultzZehden and Gee, 2013; Wichorowski et al., 2011; Zaucha 2014; Zaucha et al. 2016; Depellegrin 2016)

Another example is the regional programme for ADRiatic-Ionian maritime spatial PLANning (ADRIPLAN) (EC, 2012; Barbanti et al., 2015). ADRIPLAN aimed at delivering a commonly agreed approach to cross-border MSP. The main output of the project is a series of detailed recommendations on how to harmonise a MSP process that is customised on the Adriatic - Ionian Region characteristics and needs (Barbanti, 2015). This process is organised around the four main phases of the planning process (preparation phase, analysis and interpretation phase, planning phase and evaluation, monitoring and adaptive phase) and a short manual for MSP implementation in the Adriatic-Ionian Region.

In the context of the Atlantic Arc initiative, and following the (directions indicated by the) Atlantic Action Plan (EC, 2011a; EC, 2001b; EC, 2013), a pilot project was launched for the period 2012-14 in the Celtic Sea and Bay of Biscay, i.e. the "Transboundary Planning in the European Atlantic" (TPEA; TPEA, 2014). The Objective of TPEA was to agree on common, cross-border maritime spatial planning (MSP) methods in the European Atlantic 
region, including directions for establishing legal certainty for investors and preventing sector conflicts for marine space.

Finally, in the Black Sea, a pilot project was initiated in 2015 (EC, 2007a; EC, 2015), supported by the Regional Strategy (European Parliament, 2011) with the aim of delivering a plan for the sustainable use of the maritime space between Bulgaria and Romania.

It has become clear, from the experience gained from pilot initiatives, that for MSP to succeed it is necessary to accommodate multiple uses in the marine area. Importantly, an effective plan must be based on data that are up-to-date, objective, reliable, relevant and easily compared. A major challenge in this task is to cover the great variety of stakeholders (ranging from scientists to institutional partners and to economic operators), where each uses different types of (spatial) data and information, which in turn are often described by heterogeneous metadata and managed by distinct workflows. For these reasons, data gathering is a fundamental and critical part of the MSP process. Marine and maritime data are available through international repositories and data initiatives e.g. the European Atlas of the Seas (EC, 2013a; Barale et al., 2015), the European Environment Agency (EEA) databanks (EIONET, WISE, BISE etc.), the European Marine Observation and Data Network (EMODnet), regional sea conventions (OSPAR, HELCOM, Barcelona and Bucharest) and other national data infrastructures.

Once data are identified and gathered, harmonisation issues are likely to emerge (Fugazza et al., 2014). This is even more relevant where a diversity of national legal statuses coexist, particularly when transnational cooperation between neighbouring countries is weak and in the absence of established EEZ (Papageorgiou, 2016). In fact, data needed for the MSP process are diverse by definition, including different domains, geographical areas, spatial and temporal scales, quality and completeness of description, availability, and re-use potential. Further, data availability varies within the EU regions due to differences in applied data management around data infrastructures, documentation (specifications) and metadata catalogues.

Issues and needs related to harmonised data and metadata, available within standardised data flows (Barbanti et al., 2015) have been highlighted by most international pilot projects. These projects have also suggested common data management methods. Instead of relying exclusively on operational national databases (Vanden Eede et al., 2014; Smith et al., 2012) that focus mainly on national Exclusive Economic Zones (EEZ), MSP processes require information in the cross border context. The cross border data management issue is not a new topic in the Europe and it is expected by many to be overcome with the development of the Infrastructure for Spatial Information in European 
Community (INSPIRE), European binding data initiative (Directive 2007/2/EC). Using standards for data modelling and network services, INSPIRE aims to overcome data heterogeneity issues, to enable cross-border data and information integration and to foster the development of common European data flows. In a nutshell, INSPIRE aims to improve access, re-use, harmonisation and sharing of high quality spatial data (including coastal, marine, and maritime data) held by the public sector, in support to the implementation of EU environmental policies, as well as of policies or activities that may have an impact on the environment. Through INSPIRE, Member States (MS) are required to build a European decentralised system for sharing harmonised spatial data and information. This is required to be accessible through a set of internet-based services (network services) that allow the user to search, discover, view and download the data. The INSPIRE Directive was adopted in 2007 and it is expected to be fully operational in 2020, according to the implementation plan illustrated in Figure 1. 


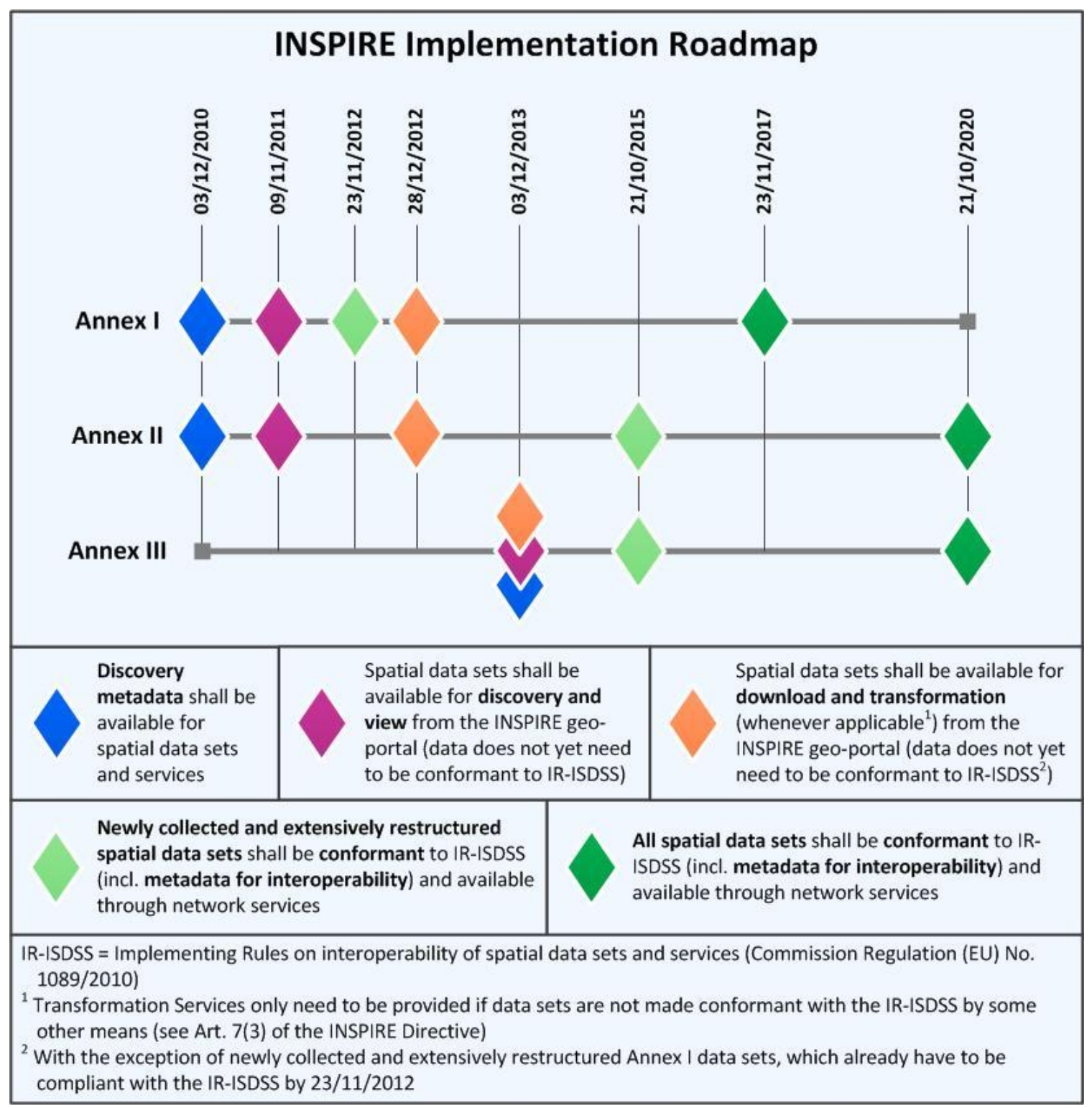

Figure 1 - INSPIRE implementation roadmap, http://inspire.ec.europa.eu

The purpose of this paper is to analyse how and if the implementation of INSPIRE can support and benefit data management processes, which are needed for setting up and implementing MSP. This includes the compilation of data, the establishment of a spatial data inventory, the re-use of reference data, and the mapping and sharing of information on existing maritime activities that are regulated by various public administrations. In particular, this research investigates whether the INSPIRE standard for spatial mapping (the so-called data model) includes all of the components required for the implementation of the MSP process, or if there is a need for additional data modelling. The investigation is done using three parallel analyses. The first analysis focuses on the MSP Directive 
and considers if its requirements are linked to INSPIRE, and if they are, how they are linked. The second analysis concerns the availability of marine and maritime data through the INSPIRE Geo-Portal. The third analysis considers the INSPIRE data model used for mapping maritime spatial plans. 


\section{Methods}

\subsection{Analysis of the relationship between the MSP and INSPIRE Directives}

This first component of this research is the analysis of the synergy between two major policies (Directives), requiring the establishment of a common European Spatial Data Infrastructure (SDI) (i.e. INSPIRE) and the cross-cutting Integrated Maritime Policy (EC, 2007; EC 2009a), which provides the overall legal framework for MSP. In particular, the analysis considered how INSPIRE, as a legal initiative that requires sharing spatial information within a European decentralised data infrastructure, already in the mature process, can be applied in achieving the goals of the MSP policy. For this purpose, all articles of the MSP Directive were examined, taking into account the requirement(s) of each article; if and how these requirements are linked to INSPIRE; which are the linked INSPIRE components (data model, data availability, discovery network services, download services, etc.); and finally the tools and benefits for planners in applying INSPIRE in the planning process. The relevant requirements specified in the MSP Directive, as they relate to the specific use of the marine space, have been mapped into the INSPIRE data model using the search machine described in section 2.3.

The analysis was performed for each article of the MSP Directive, thus including Chapter I, General Provisions: Articles 1 - 4; Chapter 2, Maritime Spatial Planning: Articles 5 - 12. Most of the articles of Chapter 3 were excluded from the analysis, as they tackle aspects that do not have a clear link with the establishment of spatial data infrastructures (e.g. administrative procedures for the definition of competent authorities, the transposition in national legislation, final provisions, entry into force and corresponding addresses).

\subsection{Analysis of maritime/marine data availability using the INSPIRE Geoportal}

The analysis of the availability of marine and maritime data through the INSPIRE GeoPortal $^{3}$ is done by accessing its Discovery/Viewer section. The Geo-Portal contains five types of metadata records: datasets; series; services; layers; and download service datasets. These are all included in the analysis. The Geo-Portal was used to search a set of English keywords related to specific marine environment and maritime activities (the full list of keywords is included in Appendix I). The keywords were selected from a vocabulary of recognised keywords used by the geo-portal and translated in all EU official languages. The vocabulary was obtained from the INSPIRE Geo-portal Operational Pilot

${ }^{3}$ website: http://inspire-geoportal.ec.europa.eu/discovery/ accessed in November 2015. 
development group of the EC Joint Research Centre (JRC). This resource is unpublished and contains a sub-group of keywords taken from official translations of the INSPIRE Directive and from the General Multilingual Environmental Thesaurus ${ }^{4}$. The use of keywords from the vocabulary, listed in the first column of Appendix I, was necessary in order to ensure that the results would include records displayed not only in English, but also in any of the other official EU languages. Basic keywords, or combinations of keywords, like "fisheries", "bathymetry", "EEZ" and "marine habitats", were not present in the official list. For this reason, the list was extended with additional keywords, listed in the second column of Appendix I.

For each identified metadata record, the following information was extracted: (1) the type of dataset; the series; the service; the layer; and the download service dataset); (2) the marine/maritime sector it refers to; (3) the country publishing the record; and (4) the European marine region or sub-region to which it belongs.

\subsection{Analysis of the INSPIRE data model used for mapping maritime spatial plans}

The relevant INSPIRE data model was identified using the Interactive Data Specifications application, publicly available on the INSPIRE website ${ }^{5}$. This application is an online tool, which was used for searching and identifying INSPIRE spatial objects in two ways. The first was through the interactive search of INSPIRE data themes, followed by the selection of the relevant application schema. The second was through the direct search, where an examination is performed on the spatial object type level and the search engine looks in the labels, definitions and descriptions of existing INSPIRE spatial objects. Finally, the identified INSPIRE application schema was tested against the real MSP use cases and the relationship between the INSPIRE data model and maritime activities, included in the studied examples, was investigated. In this analysis MSP use cases as published on the UNESCO/IOC web page of the Marine Spatial Planning Initiative were used.

\footnotetext{
${ }^{4}$ website: www.eionet.europa.eu/gemet/index_html?langcode $=e n$

${ }^{5}$ website: http://inspire.ec.europa.eu/
} 


\section{Results \& Discussion}

\subsection{The relationship between the MSP and INSPIRE Directives}

INSPIRE is a data initiative, supported by legal requirements, which applies not only to the entire body of European environmental legislation, but also to policies having an impact on the environment. The policies mapping exercise resulted in a conceptual framework to analyse the MSP Directive articles requirements against INSPIRE. The first three articles (General Provisions, Chapter I) and Article 5 define the subject matter, the scope and the objectives of the Directive, and provide definitions of fundamental terms, such as, Integrated Maritime Policy, MSP, marine region and marine waters. These articles refer to the need to develop maritime economies, including marine environment safeguards and a link to environmental legislation relating to marine waters. Analysing the scope and objective, it became clear that the MSP Directive is a policy that directly and indirectly affects the marine environment. The MSP process must consider natural resources sustainability and the protection of the marine environment, applying an ecosystem-based approach. Consequently, actions and processes required by the Articles 1, 2, 3 and 5 will have an impact on the marine environment (Kelly et al., 2014). For this reason, spatial data and information on marine use developed in the MSP process should be shared though the European SDI. The INSPIRE Directive requires sharing data and information, not only among marine/maritime stakeholders, but also to the general public through open access. Hence, spatial data sets that describe the distribution of existing and future maritime activities (marine spatial plans) should be shared as transformed/harmonised data, applying a European interoperable data format, i.e. the INSPIRE data model.

Table 1: The INSPIRE thematic scope in Directive 2007/2/EC annexes and the 34 data themes.

\begin{tabular}{|c|c|c|}
\hline Annex I & Annex II & Annex III \\
\hline Addresses & Elevation & Agricultural and Aquaculture Facilities \\
\hline Administrative Units & Geology & Area Management/Restriction/Regulation Zones \\
\hline $\begin{array}{l}\text { Cadastral Parcels } \\
\text { Coordinate Reference }\end{array}$ & Land Cover & $\begin{array}{l}\text { Atmospheric Conditions and Meteorological } \\
\text { Geographical Features }\end{array}$ \\
\hline Systems & Orthoimagery & Bio-geographical Regions \\
\hline Geographical Grid Systems & & Buildings \\
\hline Geographical Names & & Energy Resources \\
\hline Hydrography & & Environmental Monitoring Facilities \\
\hline Protected Sites & & Habitats and Biotopes \\
\hline
\end{tabular}


Human Health and Safety

Land Use

Mineral Resources

Natural Risk Zones

Oceanographic geographical features

Population Distribution

Production and Industrial Facilities

Sea Regions

Soil

Species Distribution

Statistical Units

Utility and Government Services

Further, maritime uses and activities that must be considered in the MSP process (listed in Article 8) have been mapped against the INSPIRE thematic scope. INSPIRE applies to 34 data themes (see Table 1), as "Sea regions", "Oceanographic geographical features", "Protected Sites", "Habitats and biotopes", "Species distribution" related to the marine environment and to maritime activities such as "Transport networks", "Agriculture and aquaculture facilities", "Energy resources" and "Land use" (including marine use). All activities and uses are mapped using the "Land use" INSPIRE theme that classifies a sea area according to an actual purpose (e.g. maritime transport routes). Most of the listed maritime activities (e.g. maritime transport routes) are also mapped with a second INSPIRE data theme (e.g. Transport networks) that includes specific detailed data models and more precise information related to the activity (route area, port nodes, traffic directions, separations, schemas etc.). The results of this analysis are summarised in Table 2. 
Table 2: Mapping of the relevant activities and uses of the marine space that should be considered in the MSP process (Article 8) into the INSPIRE themes and the Hierarchical INSPIRE Land (marine) Use Classification System (HILUCS).

\begin{tabular}{|c|c|c|}
\hline $\begin{array}{c}\text { Maritime use or } \\
\text { activity }\end{array}$ & $\begin{array}{c}\text { Corresponding INSPIRE } \\
\text { theme(s) }\end{array}$ & Land (marine) use HILUCS code \\
\hline aquaculture areas & $\begin{array}{l}\text { Agricultural and Aquaculture } \\
\text { Facilities; Land (marine) use }\end{array}$ & 1_4_1_Aquaculture \\
\hline fishing areas & $\begin{array}{l}\text { Agricultural and Aquaculture } \\
\text { Facilities; Land (marine) use }\end{array}$ & 1_4_2_ProfessionalFishing \\
\hline $\begin{array}{l}\text { installations and } \\
\text { infrastructures for the } \\
\text { exploration, exploitation } \\
\text { and extraction of oil, of } \\
\text { gas and other energy } \\
\text { resources, of minerals } \\
\text { and aggregates, and for } \\
\text { the production of energy } \\
\text { from renewable sources, }\end{array}$ & $\begin{array}{l}\text { Energy resources; Mineral } \\
\text { resources; ; Land (marine) use }\end{array}$ & $\begin{array}{l}\text { 2_4_EnergyProduction, } \\
\text { 2_4___FossilFuelBasedEnergyProduction, } \\
\text { 2___4_RenewableEnergyProduction }\end{array}$ \\
\hline $\begin{array}{l}\text { maritime transport } \\
\text { routes and traffic flows }\end{array}$ & $\begin{array}{l}\text { Transport networks; ; Land } \\
\text { (marine) use }\end{array}$ & 4_1_TransportNetworks, 4_1_4_WaterTransport \\
\hline military training areas & $\begin{array}{c}\text { Area } \\
\text { management/restriction/regulation } \\
\text { zones and reporting units; ; Land } \\
\text { (marine) use }\end{array}$ & 3_3_1_PublicAdministrationDefenceAndSocialSecurityServices \\
\hline $\begin{array}{l}\text { nature and species } \\
\text { conservation sites and } \\
\text { protected areas, }\end{array}$ & $\begin{array}{c}\text { Protected sites; ; Land (marine) } \\
\text { use }\end{array}$ & 6_3_2_WaterAreasNotInOtherEconomicUse \\
\hline $\begin{array}{c}\text { raw material extraction } \\
\text { areas }\end{array}$ & Land (marine) use & 1_3_3_OtherMiningAndQuarrying \\
\hline scientific research & Land (marine) use & 3_2_2_ProfessionalTechnicalAndScientificServices \\
\hline $\begin{array}{l}\text { submarine cable and } \\
\text { pipeline routes }\end{array}$ & $\begin{array}{l}\text { Utility and Governmental } \\
\text { Services; Land (marine) use }\end{array}$ & 4_3_1_ElectricityGasAndThermalPowerDistributionServices \\
\hline tourism & Land (marine) use & 3_4_CulturalEntertainmentAndRecreationalServices \\
\hline $\begin{array}{l}\text { underwater cultural } \\
\text { heritage }\end{array}$ & $\begin{array}{l}\text { Protected sites; Land (marine) } \\
\text { use }\end{array}$ & 6_3_2_WaterAreasNotInOtherEconomicUse \\
\hline
\end{tabular}

The INSPIRE data model provides interoperability (Manso et al., 2009) not only for the data sets describing a same data theme (e.g. transport data in France - transport data in Spain), but also for cross-sector thematic data (e.g. transport data - submarine cable routes) (Toth et al., 2012). Cross-sector interoperability can significantly support the MSP requirements related to land-sea interactions, included in article 6(2a) "Minimum requirements" and in Article 7 on "Land-sea interactions". Spatial data related to the processes on integrated coastal management are required to be shared through a national SDI within the implementation of the INSPIRE Directive. Data related to integrated coastal management are covered by several INSPIRE data themes, such as 
"Land use", "Population distribution", "Utility and governmental services", "Agricultural and aquaculture activities" and "Energy resources".

Article 8 requires MS to establish maritime spatial plans, covering the spatial and temporal distribution of relevant existing and future activities, before 2021. However, the development of the plans in digital format is not regulated; as stated in Article 4, "the Directive shall not interfere with Member States' competence to design and determine the format and content of that plan or those plans". This activity, although not regulated within the MSP Directive, clearly falls under the umbrella of INSPIRE and the related Commission Regulation No. 1089/2010 on the interoperability of spatial data sets. This regulation provides specific requirements in relation to the digital plans, shared data interoperability and spatial planning data model (discussed in more detail in section 3.3 of this paper).

Article 9 of the MSP Directive refers to public participation and requires that all interested parties and stakeholders "have access to the plans, once they are finalised". The INSPIRE network services for discovery, view and download within a national SDI provide already operational tools and web facilities for sharing spatial plans with stakeholders. National SDIs should be used for sharing the final plans with the EC, implementing the requirements for monitoring and reporting included in Article 14 (discussed in more detail $\begin{array}{lllll}\text { in } & \text { section } & 3.4 & \text { of } & \text { this }\end{array}$

The same information systems, National SDIs, should be used for the requirement for sharing information, which is necessary for the MSP process (Article 10), including oceanographic, physical and environmental marine data as social and economic spatial information. Moreover, Article 10 requirements on data use and sharing explicitly refer to the INSPIRE Directive, as well as to Marine Knowledge 2020 and the related EMODnet. Both INSPIRE and EMODnet aim to improve access to (marine and maritime) data, thereby supporting improved decision making, policy development and economic growth. The EMODnet system applies INSPIRE principles on data sharing with high technical and political potential to the same legal, operational, semantic and technical standards. This is to improve the interoperability of the two systems and increase European data accessibility.

Cooperation among MSs and with third countries (Articles 11 and 12) should be supported in line with INSPIRE principles on data management for sharing spatial information and should comply with interoperability requirements. Sharing interoperable/harmonised data through national SDIs allows the combination of data on planning from different national sources and the potential to integrate national plans into a spatial plan for the entire marine region or sub-region. 


\subsection{Maritime/marine data availability using the INSPIRE Geoportal and the potential of establishing a MSP data inventory within INSPIRE}

The Inspire Geo-Portal contains 1,614 unique metadata records related to the marine environment and maritime activities, out of a total set of 182,570 records. The vast majority of these are represented by datasets $(1,380)$, followed by layers $(130)$, services (77) and series (27). To date, there are no download services datasets included, which are related to the marine environment and to maritime activities described by the keywords used for the analysis. This does not mean that download services do not exist. In some cases, information on download services is included in the metadata record, as a direct link to the download service or the data provider web page.

The highest number of marine/maritime metadata in the INSPIRE Geo-Portal refers to marine ecological aspects (879). The vast majority of these (760) is related to the combination of keywords "fish + sea". This combination of keywords displays metadata describing ecological aspects of single fish species, such as abundance, presence probability, preferential and potential habitat, and recurrence, for the portion of the North Sea under French sovereignty or jurisdiction. Bathymetry (331) and maritime transport (201) are the other two sectors with the highest number of metadata. On the other end of the spectrum, maritime cultural heritage records (2), coast risk management aspects (41) and marine pollution (44) are the sectors with the lowest number of metadata. 


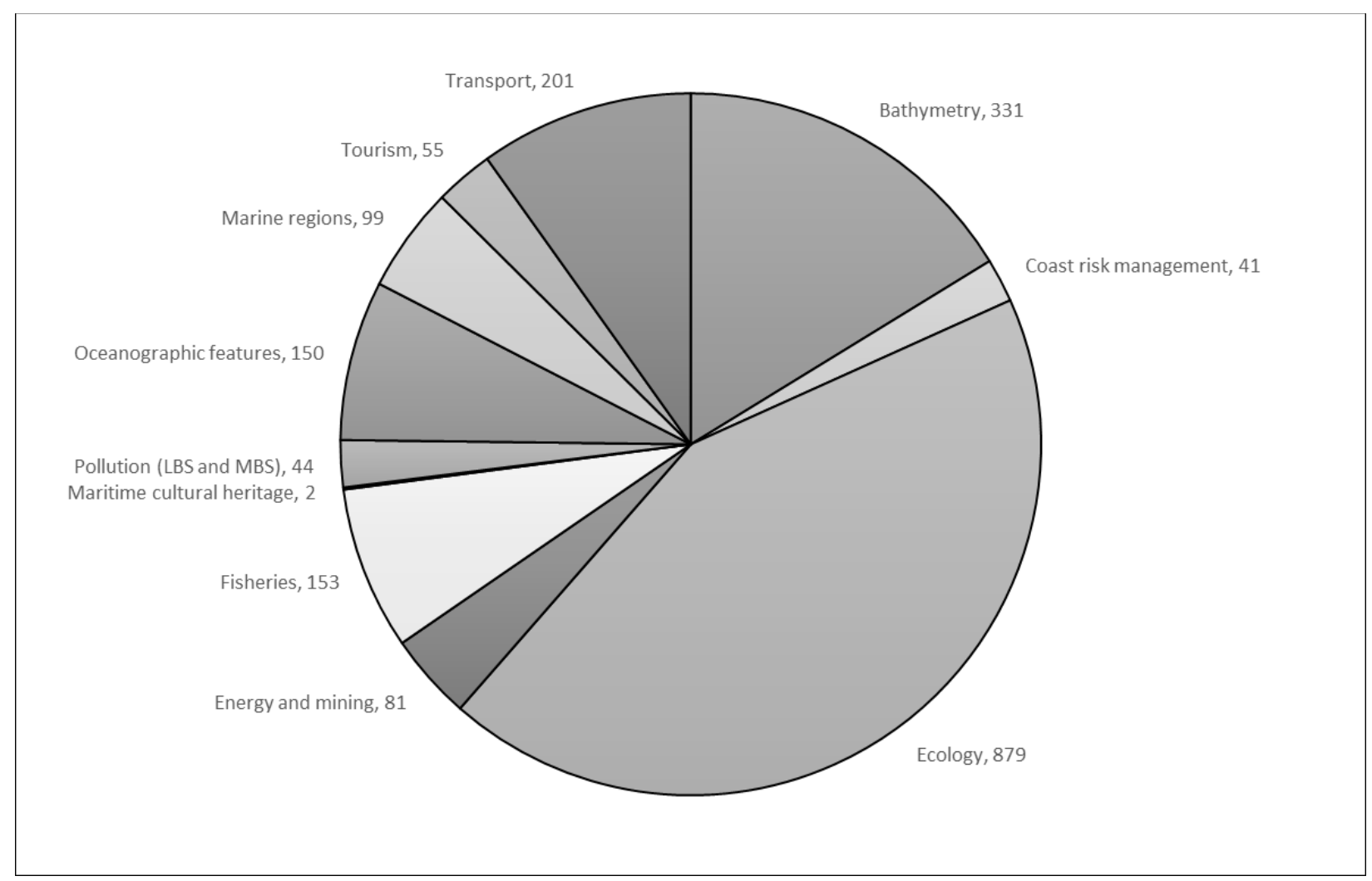

Figure 2 - Total number of metadata by sector

France (992) and the UK (340) are the two contributing countries with the largest number of marine/maritime metadata in the INSPIRE Geo-Portal. In contrast, there are five coastal MSs without any metadata records related to the marine/maritime data and services. 


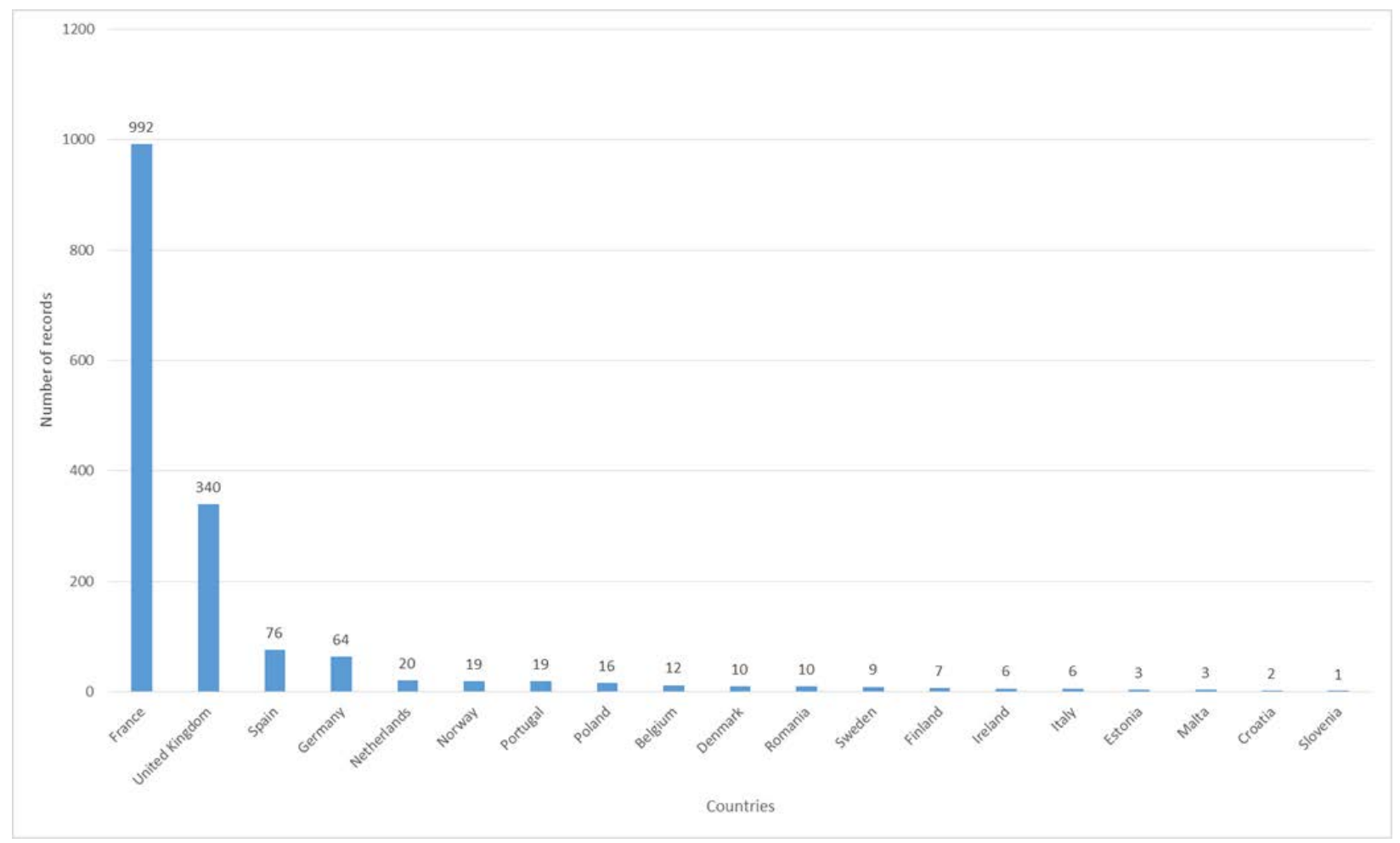

Figure 3 - Total number of metadata per country

The Greater North Sea is the marine sub-region with the highest number of metadata (1444), followed by the Bay of Biscay/lberian Coast (294) and the Western Mediterranean (264 records). The Aegean and Levantine Sea is the only marine sub-region without unique metadata. In fact, it includes only 1 metadata, which is a 2008 French dataset on the bathy-morphology of the whole Mediterranean Sea at $1000 \mathrm{~m}$ resolution. In very general terms, as presented in Figure 3, the Mediterranean Sea and the Black Sea have a much lower number of records, when compared to other marine sub-regions. As mentioned earlier, the majority of the metadata for the Greater North Sea describe ecological aspects of fish species for the French marine waters of this marine sub-region. Most metadata for the Baltic Sea are related to zooplankton datasets (20 out of 84 ). The majority of the records of the Celtic Sea are records that cover the entire marine area of the UK (190 out of 247). Examples include datasets on fish landings in UK ports, and fishing activity for UK vessels, including size and specific years. Similarly, most of the records located in the Macaronesian region derive from Spanish national datasets describing the whole Spanish marine territory in specific parameters or maritime activities under national biological and socio-economic data on pollution damage and risk. Finally, it is worth mentioning two sets of records that fall outside the geographical scope of the European marine sub-regions. The first is the set of 11 records covering the whole globe, the most notable examples of which are the snapshot datasets of Argo float data and 
metadata, from the Argo Global Data Assembly Centre (GDAC). The second is the set of 31 metadata describing marine and maritime features of French Overseas Territories (namely, French Antilles, French Guyana, French New Caledonia, Réunion, Crozet, Saint Paul and Amsterdam Islands), and UK seismic datasets retained by the British Institutes Reflection Profiling Syndicate (BIRPS) describing various parts of the world, such as Mexico and Indonesia, among others.

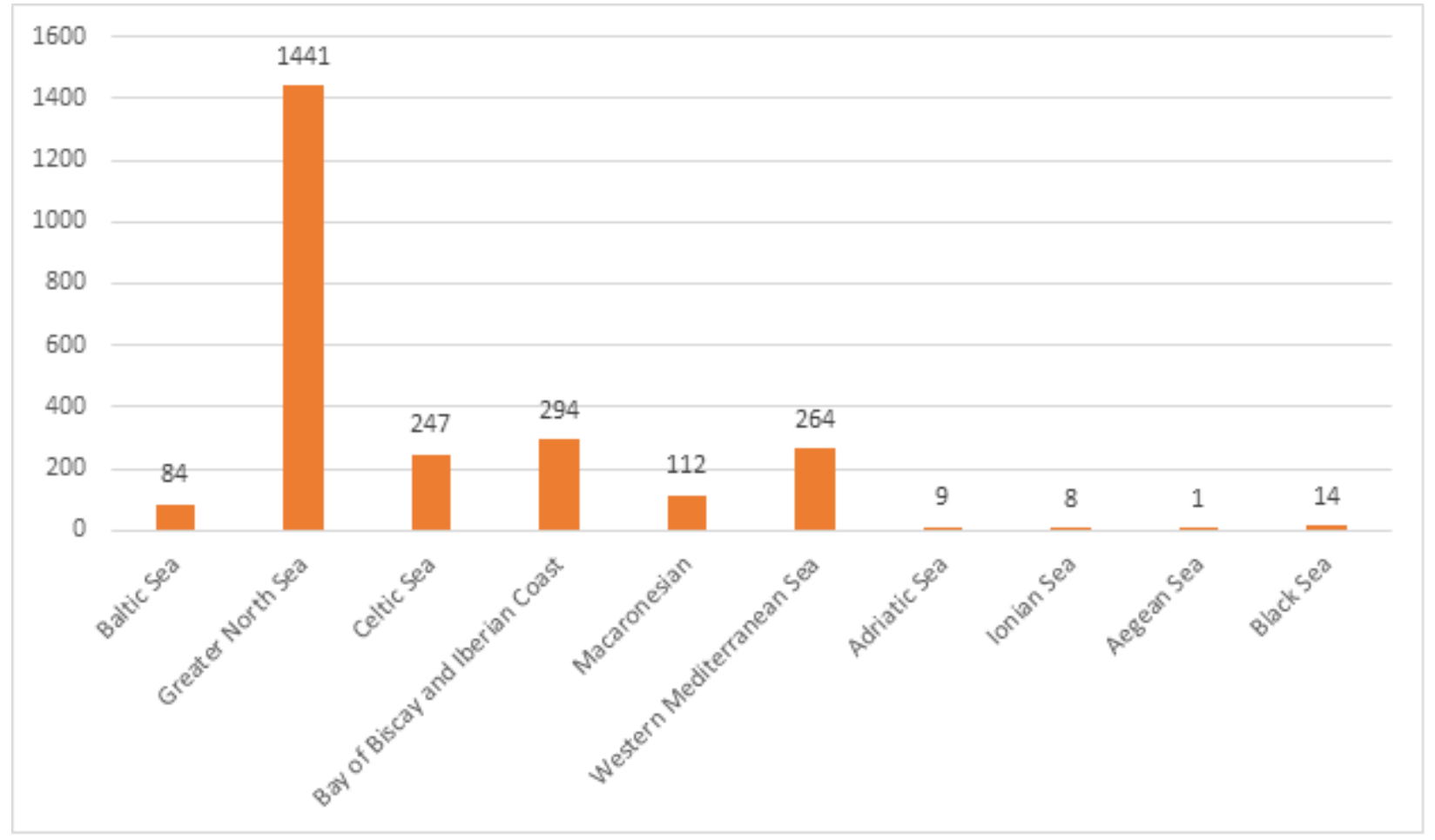

Figure 4 - Total number of metadata by marine sub-region.

The analysis of marine data availability shows that, currently, the INSPIRE Geo-Portal does not have the capacity to fully support the MSP process. The number of marinerelated metadata records available in the geoportal is low (only $0.8 \%$ of Geo-Portal records relate to the marine environment and maritime activities) with some EU coastal countries not publishing any information on shared marine/maritime data. Moreover, records distribution across maritime sectors and marine regions is unbalanced, with data on ecological aspects and bathymetry comprising more than half of existing marine metadata records. Differences in the data quantity are significant also between marine regions, with the Greater North Sea having a greater number of metadata records than the sum of all other marine regions and sub-regions. In general terms, this reflects the varying capacity and commitment of MSs to share marine/maritime information and render it discoverable through national SDIs and the INSPIRE Geo-Portal. States such 
as France, United Kingdom, Spain and Germany are paving the way, but there are many other European coastal countries lagging behind. This confirms that the implementation of INSPIRE is still an ongoing process. It is expected that the amount of INSPIRE compliant spatial information, publicly available and searchable through the INSPIRE Geo-Portal, will increase exponentially, in parallel with the INSPIRE implementation roadmap (as in Figure 1). The implementation of INSPIRE will provide a major benefit/contribution to the MSP process, because it will unlock a large quantity of reliable, harmonised and high-quality data across states and sectors. This will be necessary to support the MSP onset in the EU.

\subsection{The INSPIRE data model used for mapping maritime spatial plans}

The INSPIRE website that hosts the Interactive Data Specification web application was assessed in considering MSP Directive Article 8 on Monitoring and reporting and Commission Regulation No. 1089/2010 on the interoperability of spatial data sets. Interactive Data Specification was used to identify INSPIRE themes and the related application schema that allow the mapping of maritime planned activities. The "find your scope" function was used to browse through definitions and descriptions of the spatial objects, application schemas and INSPIRE themes.

\section{Table 3 - Results of analysis with Interactive Data Specifications application}

\begin{tabular}{||c||c||c||c||c||c||}
\hline Search term & N results & $\begin{array}{c}\text { N of results } \\
\text { in relation to } \\
\text { MSP }\end{array}$ & $\begin{array}{c}\text { N of } \\
\text { Objects }\end{array}$ & Application Schemas & Themes \\
\hline \hline $\begin{array}{c}\text { Maritime } \\
\text { spatial } \\
\text { planning }\end{array}$ & $\begin{array}{c}\text { did not match any } \\
\text { label, definition or } \\
\text { description of selected } \\
\text { INSPIRE object } \\
\text { categories }\end{array}$ & 0 & & & \\
\hline $\begin{array}{c}\text { Marine } \\
\text { spatial } \\
\text { planning }\end{array}$ & $\begin{array}{c}\text { did not match any } \\
\text { label, definition or } \\
\text { description of selected } \\
\text { INSPIRE object } \\
\text { categories }\end{array}$ & 0 & & & \\
\hline
\end{tabular}




\begin{tabular}{|c|c|c|c|c|c|}
\hline Marine & 24 & 24 & & $\begin{array}{l}\text { Water Transport Network, Sea } \\
\text { Regions, Area Management } \\
\text { Restriction and Regulation } \\
\text { Zones, Geology, Mineral } \\
\text { Resources, Bio-geographical } \\
\text { Regions, Administrative and } \\
\text { Social Governmental Services, } \\
\text { Habitats and Biotopes, Soil, } \\
\text { Species Distribution, Common } \\
\text { Transport Elements }\end{array}$ & $\begin{array}{l}\text { Sea Regions, } \\
\text { Protected Sites, } \\
\text { Agricultural and } \\
\text { Aquaculture } \\
\text { Facilities, } \\
\text { Hydrography, } \\
\text { Habitats and } \\
\text { Biotopes, } \\
\text { Meteorological } \\
\text { geographical } \\
\text { features }\end{array}$ \\
\hline Maritime & 5 & 5 & 5 & $\begin{array}{l}\text { Maritime Units, Production } \\
\text { and industrial facilities, Water } \\
\text { transport network }\end{array}$ & \\
\hline $\begin{array}{l}\text { spatial } \\
\text { planning }\end{array}$ & 4 & 4 & 3 & $\begin{array}{l}\text { Planned Land Use, Protected } \\
\text { Sites Simple }\end{array}$ & Land Use \\
\hline planning & 4 & 4 & 3 & $\begin{array}{l}\text { Planned Land Use, Protected } \\
\text { Sites Simple }\end{array}$ & Land Use \\
\hline $\begin{array}{c}\text { marine } \\
\text { spatial plan }\end{array}$ & $\begin{array}{l}\text { did not match any } \\
\text { label, definition or } \\
\text { description of selected } \\
\text { INSPIRE object } \\
\text { categories }\end{array}$ & 0 & & & \\
\hline $\begin{array}{l}\text { Maritime } \\
\text { spatial plan }\end{array}$ & $\begin{array}{l}\text { did not match any } \\
\text { label, definition or } \\
\text { description of selected } \\
\text { INSPIRE object } \\
\text { categories }\end{array}$ & 0 & & & \\
\hline spatial plan & 5 & 5 & 4 & $\begin{array}{c}\text { Planned Land Use, Protected } \\
\text { Sites Simple }\end{array}$ & Land Use \\
\hline
\end{tabular}

Performing the search with the Interactive Data Specifications application, we obtained clear results regarding the application schema that should be used for MSP mapping (see Table 3). The spatial planning data model is included in the INSPIRE data theme "Land Use". Even though the Planned Land Use data model was originally developed for terrestrial planning, as specified in the Technical Guidelines document on "INSPIRE Data Specification on Land Use", the uses and planning of the sea were considered correspondingly during the development process (EC/JRC, 2013).

The "Planned Land Use" conceptual data model includes various features, including the Spatial Plan and Zoning Element feature(s), the Official Documentation feature(s) and Supplementary Regulation feature(s). The related conceptual model is illustrated in Figure 5. The Spatial Plan is a parent set of documents, which includes the Zoning Element feature(s) that presents regulated allocations for permitted uses and activities. 
The Spatial Plan also includes features that provide information on legal requirements such as Official Documentation feature(s) and Supplementary Regulation feature(s). The Official Documentation is a mandatory feature (or features) that includes applicable legislation, regulations, cartographic elements and descriptive elements, which may be associated with the complete spatial plan, or refer to the Zoning Elements. The Supplementary Regulation (the inclusion of which in the Spatial Plan is not mandatory) is a spatial object (point, line or polygon) that provides supplementary information and/or limitation of the use of land/sea. This is necessary for spatial planning purposes and/or for formalising external rules defined in a legal text (e.g. limitation related to the United Nation Convention on the Law of the Sea or any other international, European or national legal instrument).

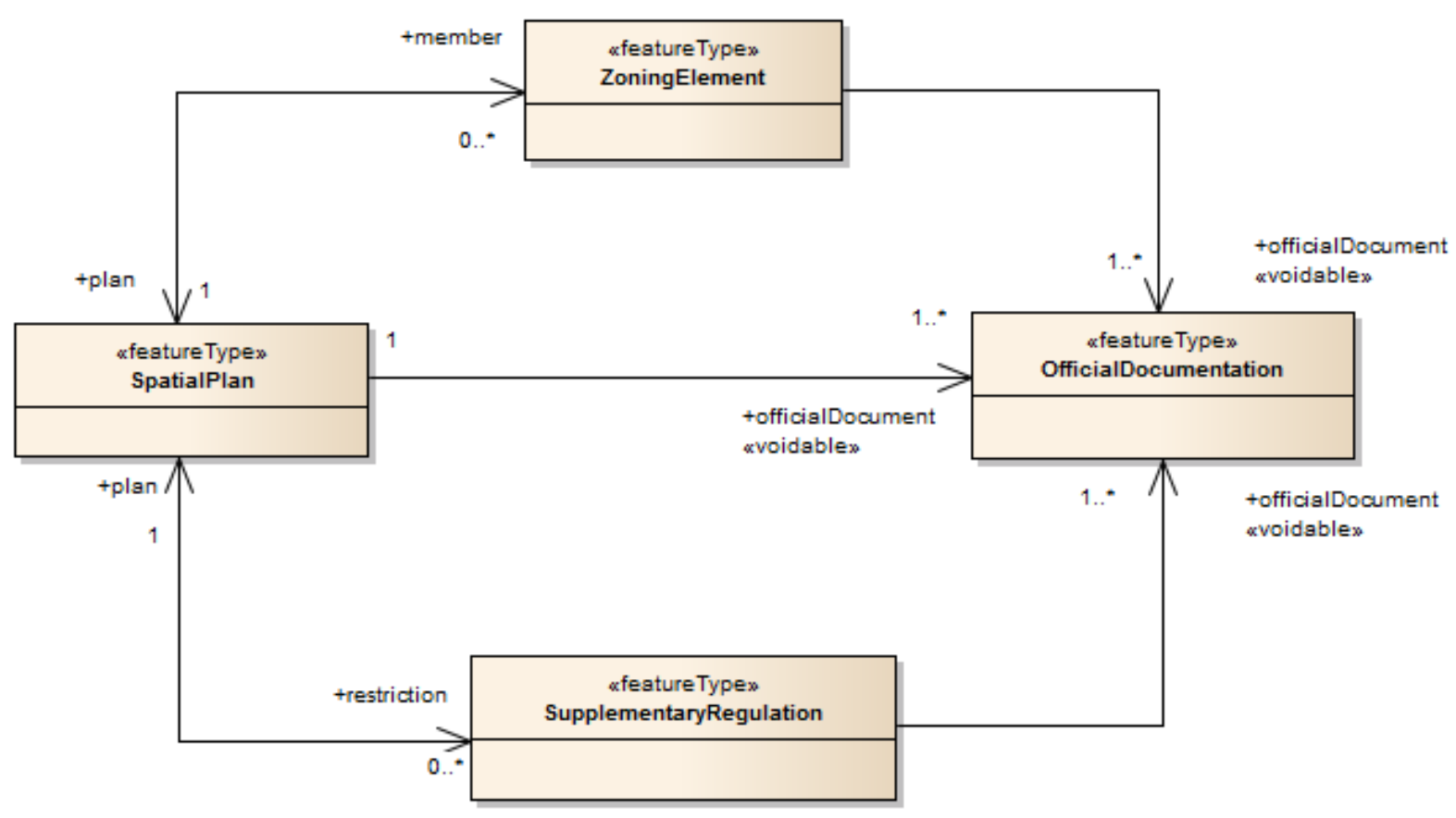

Figure 5 - Overview of the INSPIRE "Planned land (marine) use" conceptual model. (This figure is extracted from the INSPIRE UML data model repository publicly available in HTML format at http://inspire.ec.europa.eu/)

\subsubsection{Hierarchical INSPIRE Land Use Classification System applied in MSP \\ The planned use of each Zoning Element feature is specified through a compulsory attribute that includes Hierarchical INSPIRE Land Use Classification System (HILUCS) value (EC/JRC 2013). HILUCS is a multi-level classification system of 98 land/marine use categories, developed for spatial planning and tested in this study for the spatial objects commonly used in MSP. Spatial objects that represent marine use are extracted from publicly available documents on marine spatial plans available at the}


UNESCO/IOC Marine Spatial Planning Initiative webpage (for example, the Spatial Plan for the German Exclusive Economic Zone - North Sea, the Master Plan for the sustainable use of the Belgian Part of the North Sea and the Trilateral Wadden Sea Plan). The examples used in the analysis are given in Table 4.

\section{Table 4 - Examples of MSP common spatial objects mapped into HILUCS}

\begin{tabular}{|l|l|}
\hline Spatial object & HILUCS \\
\hline $\begin{array}{l}\text { Reservation Area } \\
\text { Shipping }\end{array}$ & 4_1_4_WaterTransport \\
\hline Priority Area Shipping & 4_1_4_WaterTransport \\
\hline $\begin{array}{l}\text { Traffic Separation } \\
\text { Scheme }\end{array}$ & 4_1_4_WaterTransport \\
\hline Offshore wind energy & 2_4_4_RenewableEnergyProduction \\
\hline Offshore wave energy & 2_4_4_RenewableEnergyProduction \\
\hline Offshore tidal energy & 2_4_4_RenewableEnergyProduction \\
\hline $\begin{array}{l}\text { High Voltage Cable (in } \\
\text { use) }\end{array}$ & 4_3_1_ElectricityGasAndThermalPowerDistributionServices \\
\hline $\begin{array}{l}\text { Reservation Area for } \\
\text { Pipelines }\end{array}$ & 4_3_1_ElectricityGasAndThermalPowerDistributionServices \\
\hline Priority Area for Pipelines & 4_3_1_ElectricityGasAndThermalPowerDistributionServices \\
\hline Natural Gas pipeline & 4_3_1_ElectricityGasAndThermalPowerDistributionServices \\
\hline
\end{tabular}

The HILUCS classification system is not an extendable code list. It provides general, non-specific information, which does not completely satisfy all possible maritime uses. However, it allows comparison of the different data sets developed and provided from different sources and/or data providers. In order to deliver more specific information on marine/maritime uses, the feature "Zoning Element", illustrated in Figure 6, includes an additional non mandatory attribute - specificLandUse. This attribute includes any value defined by the spatial data provider (e.g. shallow sea offshore wave energy VS HILUCS 2_4_4_RenewableEnergyProduction) and it is able to remove any ambiguity on marine use. 


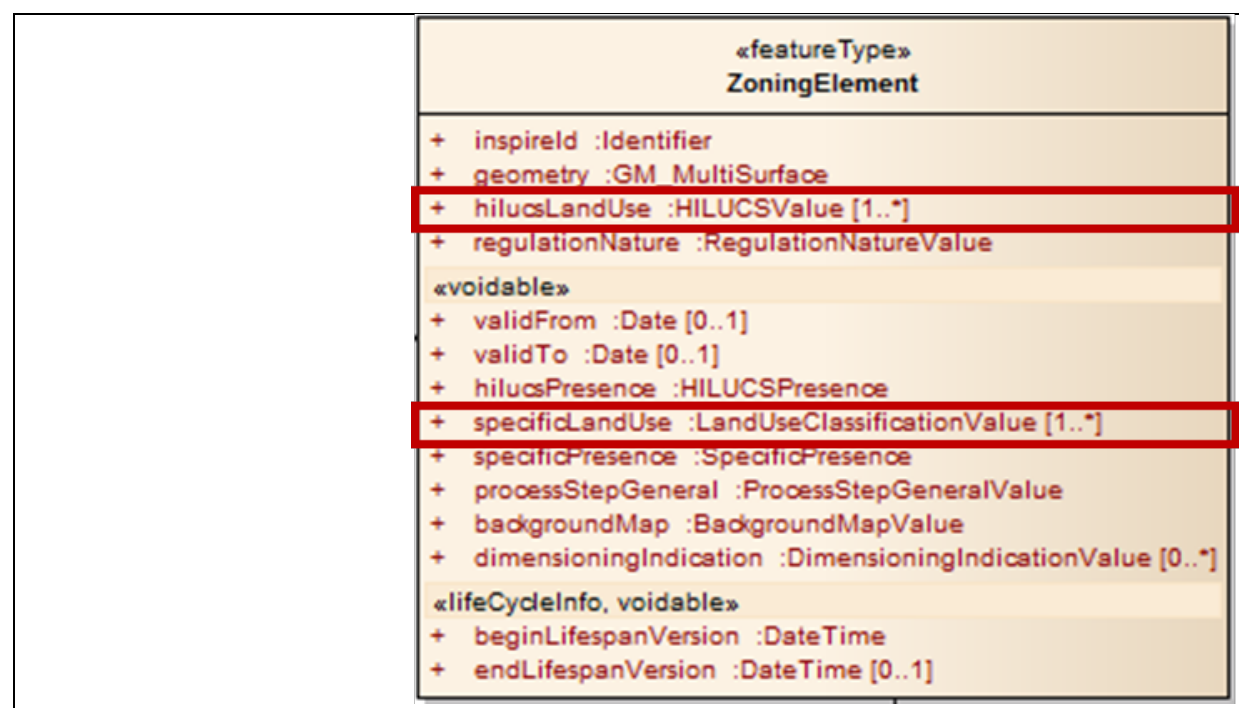

Figure 6 - Zoning Element feature, with obligatory (hilucsLandUse: HILUCSValue) and non-obligatory (specificLandUse: LandUseClassificationValue) attributes. Figure 6 is extracted from the INSPIRE UML data model repository publicly available in HTML format at http://inspire.ec.europa.eu/

Currently, there are difficulties in harmonising the vision and frameworks of maritime spatial plans of countries sharing the same marine region or sub-region, beyond national EEZ areas, even in the most advanced European examples. This is in part due to the fact that plans do not use harmonised data models, standard rules for layers and styles for portrayal of the spatial object types delivered in the spatial plan. The issues identified and reported during the implementation of the various joint European maritime planning initiatives and pilot projects, could be resolved by applying INSPIRE standards on data sets, layers and portrayal of marine spatial plans. Spatial plans developed by different member states could be combined and, without significant effort, delivered together, obtaining the overview of planned areas that are much greater than any national EEZ.

The Planned Land Use data model and the corresponding INSPIRE application schema were identified as appropriate for modelling maritime spatial plans. The INSPIRE data model proved to be relatively complete and to provide a standard for spatial plans that consists of zoning elements, official documentation and supplementary regulation features (see Figure 5). Examinations and tests of the data model with the published maritime spatial plans examples provided positive results and did not point out any incompatibilities with planned marine use (Table 4 and Figure 6). The Planned Land Use 
data model is robust enough to encode actual maritime spatial plans, including standard zoning elements and standard interoperable code classification system, such as HILUCS, which combine more specific codes defined by data developers. Additionally, the data model provides the possibility of including entire textual regulations and allows official documentation to be used as a part of the spatial data set. An alternative, and probably a preferable solution, is that a simple reference (Uniform Resource Locator) to the planning legislation is included in the official documentation feature.

Another advantage of using the INSPIRE Planned Land Use data model is the potential for the successful integration of marine and terrestrial planning. Importantly, there would be no need for the development of a coastal zone interface, as the use of the INSPIRE data model guarantees that marine spatial plans are completely compatible with INSPIRE-compliant land planning. By applying INSPIRE interoperability standards in both marine and terrestrial spatial plans, it would be possible to provide a merged overview, even when spatial information are developed and managed by different institutions. Integration of marine and terrestrial spatial plans using the INSPIRE data model would facilitate land sea interaction analysis using HILUCS classified land objects and classified maritime activities, as integration of MSP with Integrated Coastal Zone Management, as specifically required in Article 6 of MSP Directive.

Finally, the use of the INSPIRE data model in MSP can assist in providing strategic direction for the development and management of marine and coastal geographic areas, as it allows the establishment of zoning priorities, fixed allocations and policies for strategic guidance of activities in marine areas. The INSPIRE Planned Land Use application schema is compatible with, and supports the development of, maritime plans in the scope of the MSP Directive. Hence, within INSPIRE, the change of reference terminology from "Planned Land Use" to "Planned Land/Marine Use" would be appropriate.

\subsection{Use of INSPIRE-compliant network services within MSP}

The process of preparation and implementation of maritime plans should be publicly transparent (Mayer et al., 2013; Soma et al., 2015), while related spatial data should be available through the national and European SDIs (INSPIRE). INSPIRE network services, which allow users to discover, view and download spatial information, are based on standards and established protocols (e.g. those of the Open Geospatial Consortium and International Organisation for Standardisation), which are highly developed and can be simply established using both free-of-charge (e.g. GeoServer, Mapserver, GeoNetwork and Deegree) and commercial (e.g. ESRI, SnowFlake and FMI) software solutions. The 
use of efficient software for the development of INSPIRE-compliant network services in the scope of the MSP for sharing drafts and final spatial plans can improve and technically update the interactions of stakeholders during the planning process. This is a logical step that is invoked by technology development, particularly of intuitive and user-friendly software. Finally, the use of the INSPIRE network services in maritime spatial planning would significantly increase the transparency of the process.

Article 14 on Monitoring and reporting of the MSP Directive states "Member States shall send copies of the maritime spatial plans, including relevant existing explanatory material on the implementation of this Directive, and all subsequent updates, to the Commission and to any other Member States concerned within three months of their publication." This paper-based requirement could be replaced by e-reporting, a concept that is being introduced in Europe in other domains, such as the Air Quality Directive 2008/50/EC (Kotsev et al., 2014). Before being widely adopted this approach is being tested by the EC JRC in collaboration with a limited number of MSs as a pilot project on Air Quality ereporting. Instead of distributing multiple copies of MSP plans, a MS could publish spatial plans through the INSPIRE compliant network services (see Figure 7) using their national SDI. This would fulfil two legal requirements at the same time (the MSP Directive monitoring and reporting and the obligation to share spatial data included in the INSPIRE Directive) and it would reduce the administrative burden.

The concept of e-reporting would allow complete transparency and an immediate update of the modifications of the plans. The monitoring and evaluation phase could initiate iterative plan modifications, where updates, using INSPIRE network services, would be promptly and publicly available. Moreover, data would be maintained by the same subjects that developed the plans, in this way avoiding multiplication of spatial plan copies and issues with outdated versions. This concept would update distributed national and European SDI, replacing the development of ad hoc central information systems for MSP data reporting. 


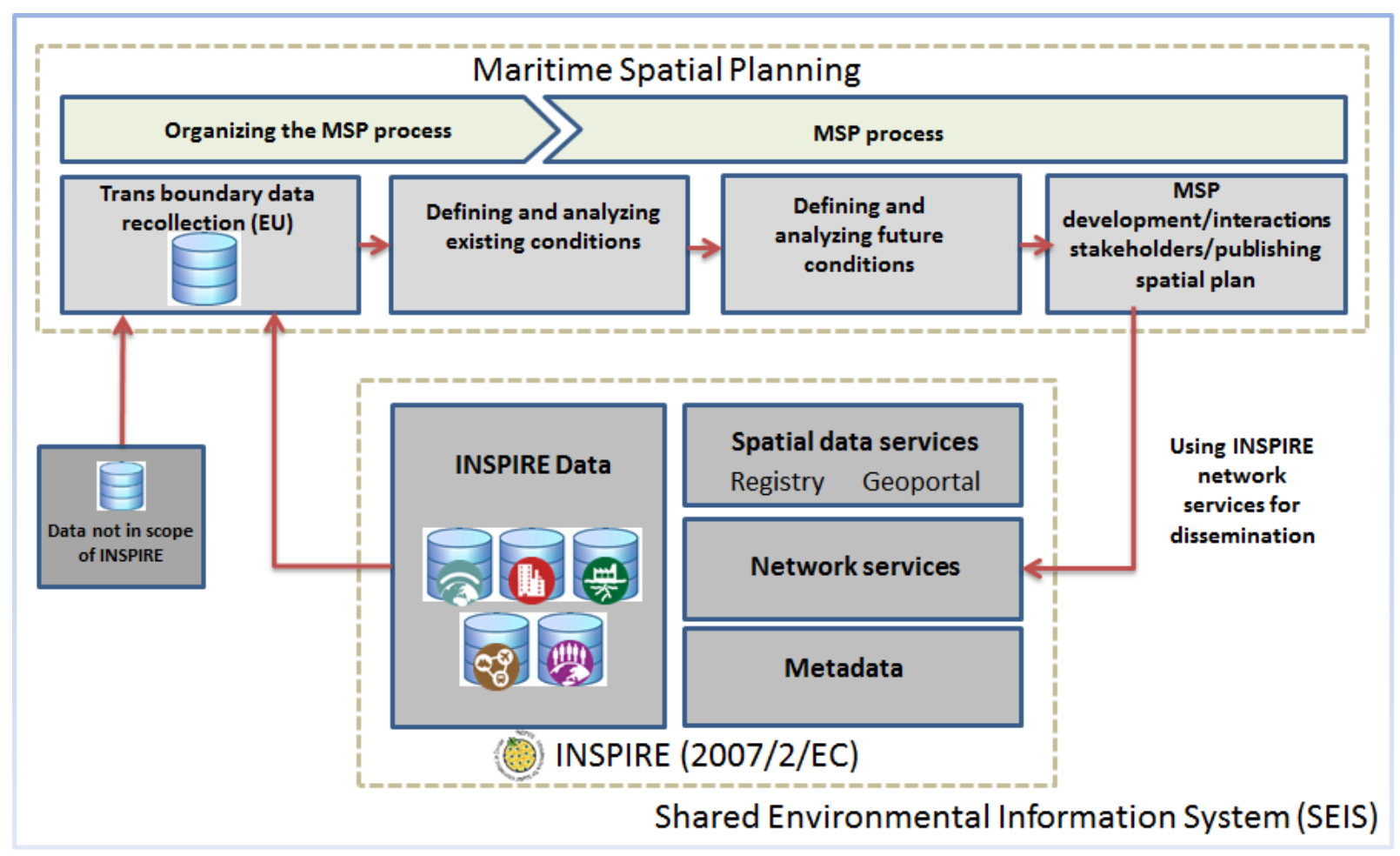

Figure 7- MSP in the context of the INSPIRE/SEIS framework (iterative process). SEIS Shared Environmental Information System (EC, 2008a) 


\section{Conclusions}

The policy mapping exercise identified robust links between the MSP Directive and the development of the European SDI, in line with INSPIRE legislation. The research shows that the use of spatial data on maritime activities and marine environment during the MSP process is essential. Marine and maritime data are included in the INSPIRE thematic scope, and as such are legally required to be shared through European SDIs. The analysis of data availability highlights big differences between European marine regions where, for example, the Greater North Sea sub-region has the greatest number of records and, in fact, as many as all other marine areas in the EU. Currently, available data is not adequate to fully support European MSP processes. However, the development of INSPIRE is still ongoing and data availability is expected to increase significantly within the next few years in line with INSPIRE implementation roadmap.

The MSP process aims to integrate the planning of all maritime activities and this will undoubtedly have beneficial impacts overall on the marine environment. All new maritime spatial plans will fall under the INSPIRE umbrella and need to be shared through INSPIRE compliant network services, including discovery, view and download.

Use of already-operational national SDI for sharing spatial plans is convenient and will significantly increase the transparency of the MSP processes. This should also lead to better planning outcomes. Sharing spatial plans through the national SDI is a concrete alternative to classical reporting and it can avoid the issues of multiple non-updated copies.

The Planned land use INSPIRE data model is appropriate and can assist in the harmonisation of maritime spatial plans within and between different marine areas, regions and sub-regions. The use of the Planned land use data model could facilitate the integration of marine and terrestrial spatial planning. It could also provide a basis for greater coherence and integration of coastal zone management.

The proposed conceptual framework can be applied beyond European borders, but only if available local/national/regional spatial data follow INSPIRE concepts on data sharing.

\section{Acknowledgements}

This research was self-funded and was developed over a number of years of collaboration between the authors. The findings of the research were used for the development of the successful PLASMAR project proposal within the INTERREG Macaronesia framework. 


\section{References}

ADRIPLAN, 2015. Adriatic Ionian Marine Spatial Planning. WWW document: http://adriplan.eu/ (accessed 23.05.2015).

Ardron, J., Gjerde, K., Pullen, S., Tilot, V., 2008. Marine spatial planning in the high seas. Mar. Policy 32, 832-839. doi:10.1016/j.marpol.2008.03.018

Backer, H., \& Frias, M. 2013. Planning the Bothnian Sea -key findings of the Plan Bothnia project. Digital edition. ISBN 978-952-67205-5-5.

Bagrow, L., 2010 (2nd Edition). History of Cartography. Revised and enlarged by R.A. Skelton. New Brunswick (USA) and London (UK): Transaction Publishers.

BaltSeaPlan, 2012. BaltSeaPlan Vision 2030 - towards the Sustainable Planning of Baltic Sea Space. WWW document :http://www.baltseaplan.eu/ (accessed 12.04.2015).

Barale, V., Assouline, M., Dusart, J., Gaffuri, J., 2015. The European Atlas of the Seas: Relating Natural and Socio-Economic Elements of Coastal and Marine Environments in the European Union. Mar. Geod. 38, 79-88. doi:10.1080/01490419.2014.909373

Barbanti A., Campostrini P., Musco F., Sarretta A., Gissi E.,2015. ADRIPLAN Conclusions and Recommendations: A short manual for MSP implementation in the Adriatic -Ionian Region. CNR-ISMAR, Venice, IT.

Bengtsson, R., 2009. An EU Strategy for the Baltic Sea Region: Good Intentions Meet Complex Challenges. Eur. Policy Anal. 12

Bigagli, E., 2015. The EU legal framework for the management of marine complex social-ecological systems. Mar. Policy 54, 44-51. doi:10.1016/j.marpol.2014.11.025

Brennan, J., Fitzsimmons, C., Gray, T., Raggatt, L., 2014. EU marine strategy framework directive (MSFD) and marine spatial planning (MSP): Which is the more dominant and practicable contributor to maritime policy in the UK? Mar. Policy 43, 359-366. doi:10.1016/j.marpol.2013.07.011

Day, J., 2008. The need and practice of monitoring, evaluating and adapting marine planning and management-lessons from the Great Barrier Reef. Mar. Policy 32, 823-831. doi:10.1016/j.marpol.2008.03.023

Depellegrin, D., 2016. Assessing cumulative visual impacts in coastal areas of the Baltic Sea. Ocean Coast. Manag. 119, 184-198.

doi:10.1016/j.ocecoaman.2015.10.012

Douvere, F., Ehler, C.N., 2009. New perspectives on sea use management: Initial findings from European experience with marine spatial planning. J. Environ. Manage. doi:10.1016/j.jenvman.2008.07.004 
Dubois, M., Hadjimichael, M., Raakjær, J., 2016. The rise of the scientific fisherman: Mobilising knowledge and negotiating user rights in the Devon inshore brown crab fishery, UK. Mar. Policy 65, 48-55. doi:10.1016/j.marpol.2015.12.013

Ehler, C.N., Douvere, F., 2009. Marine Spatial Planning: A Step-by-step Approach toward Ecosystem-based Management. IOC Manuals Guid. 53, 99

Ellis, R., 1994. Monsters of The Sea: The History, Natural History, and Mythology of the Oceans' Most Fantastic Creatures. New York: Knopf.

EU Commission, 2013. Action Plan for a Maritime Strategy in the Atlantic area, COM. doi:10.2771/27192

EU Commission, 2013a. European Atlas of the Seas [WWW Document]. Eur. Comm. URL

http://ec.europa.eu/maritimeaffairs/atlas/seabasins/mediterranean/long/index_en.ht $\mathrm{m}$

EU Commission, 2007. An Integrated Maritime Policy for the European Union COM/2007/575 final, 10.10.2007.

EU Commission, 2007a, Communication from The Commission to the Council and the European Parliament, Black Sea Synergy - A new regional Cooperation Initiative, $\operatorname{COM(2007)} 160$ final

EU Commission, 2008. Communication from the Commission - Roadmap for Maritime Spatial Planning: Achieving Common Principles in the EU. COM/2008/0791 final, Document 52008DC0791, 25.11.2008, 11 pp.

EU Commission, 2008a. Communication towards a Shared Environmental Information System - SEIS 2008. (COM(2008) 46 final).

EU Commission, 2009. The European Union strategy for Baltic Region, Background and Analysis, ISBN 978-92-79-15757-8, doi:10.2776/18241.

EU Commission, 2009a. Towards an Integrated Maritime Policy for better governance in the Mediterranean", COM/2009/466 final, 11.9.2009.

EU Commission, 2009b. Communication from the Commission to the European Parliament, the Council, the European Economic and Social Committee and the Committee of the Regions concerning the European Union Strategy for the Baltic Sea Region (COM(2009)248 final).

EU Commission, 2010. Communication from the Commission to the European Parliament, the Council, the European Economic and Social Committee and the Committee of the Regions - Maritime Spatial Planning in the EU: achievements and future development. COM/2010/0771 final, Document 52010DC0771, 17.12.2010, $12 \mathrm{pp}$.

EU Commission, 2011a, Communication from the Commission to the European Parliament, the Council, the European Economic and Social Committee and the 
Committee of the Regions, Developing a Maritime Strategy for the Atlantic Ocean Area, $\operatorname{COM}(2011) 782$ final.

EU Commission, 2011b, Maritime policy: new strategy for growth and jobs in the Atlantic Ocean area, press release, IP/11/1456.

EU Commission, 2012, A Maritime Strategy for the Adriatic and Ionian Seas, COM/2012/713 final.

EU Commission, 2013a. Proposal for a Directive of the European Parliament and of the Council establishing a framework for maritime spatial planning and integrated coastal management, COM/2013/133 final,12.03.2013, 35 pp.

EU Commission, 2013b. Commission Staff Working Document: Impact Assessment accompanying the document Proposal for a Directive of the European Parliament and of the Council establishing a framework for maritime spatial planning and integrated coastal management. SDW/2013/65 final, 12.03.2013, 117 pp.

EU Commission, 2015, Joint Staff Working Document, Black Sea Synergy: review of a regional cooperation initiative, $\operatorname{SWD}(2015) 6$ final.

EU Commission/Joint Research Centre, 2013. Technical guidance document INSPIRE Data Specification for the spatial data theme Land Use, ver. 3.0, WWW document, published by European Commission /Joint Research Centre.

EU Parliament, 2011. Resolution on an EU Strategy for the Black Sea, (2010/2087(INI)).

European Union, 2007. Directive 2007/2/EC of the European Parliament and of the council of 14 March 2007 establishing an Infrastructure for Spatial Information in the European Community (INSPIRE). Off. J. Eur. Union 50, 1-14

European Union, 2014. Directive 2014/89/EU of the European Parliament and of the Council of 23 July 2014 establishing a framework for maritime spatial planning. OJ Eur Union,L 257, 28.8.2014, p. 135-145

Fugazza, C., Basoni, A., Menegon, S., Oggioni, A., Pavesi, F., Pepe, M., Sarretta, A., Carrara, P., 2014. RITMARE: Semantics- Aware harmonisation of data in Italian marine research, in: Procedia Computer Science. pp. 261-265.

doi:10.1016/j.procs.2014.06.041

Intergovernmental Oceanographic Commission, 2006. Visions for a sea change. Rep. First Int. Mar. Spat. Plan. 84

Kelly, C., Gray, L., Shucksmith, R.J., Tweddle, J.F., 2014. Investigating options on how to address cumulative impacts in marine spatial planning. Ocean Coast. Manag. 102, 139-148. doi:10.1016/j.ocecoaman.2014.09.019

Kotsev, A., Peeters, O., Smits P., Grothe M., 2015. Building bridges: experiences and lessons learned from the implementation of INSPIRE and e-reporting of air quality data in Europe. Earth Science Informatics. Volume 8, Issue 2, pp 353-365. 
Manso, M.-Á., Wachowicz, M., Bernabé, M.-Á., 2009. Towards an integrated model of interoperability for spatial data infrastructures. Trans. GIS 13, 43-67. doi:10.1111/j.1467-9671.2009.01143.x

Mayer, I.S., Zhou, Q., Lo, J., Abspoel, L., Keijser, X., Olsen, E., Nixon, E., Kannen, A., 2012. Integrated Ecosystem-based Marine Spatial Planning: First Results from International Simulation-Game Experiment, in: Third International Engineering Systems Symposium CESUN 2012, Delft University of Technology, 18-20 June 2012. pp. $18-20$

MESMA, 2009. Monitoring and Evaluation of Spatially Managed Areas. WWW document: http://www.msprn.net/?option=com_msprn\&view=project\&id=23 (accessed 23.05.2015).

Papageorgiou, M., 2016. Marine spatial planning and the Greek experience, Marine Policy. doi:10.1016/j.marpol.2016.09.003

Pranzini, E., Wetzel, L., Williams, A.T., 2015. Aspects of coastal erosion and protection in Europe. J. Coast. Conserv. 19, 445-459. doi:10.1007/s11852-0150399-3

Schaefer, N., Barale, V., 2011. Maritime spatial planning: Opportunities \& challenges in the framework of the EU integrated maritime policy. J. Coast. Conserv. 15, 237-245. doi:10.1007/s11852-011-0154-3

Schultz-Zehden, A., Gee, K. 2013. BaltSeaPlan Findings - Experiences and Lessons. Berlin. S.Pro.

Smith, G., Brennan, R.E., 2012. Losing our way with mapping: Thinking critically about marine spatial planning in Scotland. Ocean Coast. Manag. 69, 210-216. doi:10.1016/j.ocecoaman.2012.08.016

Soma, K., van Tatenhove, J., van Leeuwen, J., 2015. Marine Governance in a European context: Regionalization, integration and cooperation for ecosystembased management. Ocean Coast. Manag. 117, 4-13.

doi:10.1016/j.ocecoaman.2015.03.010

Stelzenmüller, V., Breen, P., Stamford, T., Thomsen, F., Badalamenti, F., Borja, Á., Buhl-Mortensen, L., Carlstöm, J., D’Anna, G., Dankers, N., Degraer, S., Dujin, M., Fiorentino, F., Galparsoro, I., Giakoumi, S., Gristina, M., Johnson, K., Jones, P.J.S., Katsanevakis, S., Knittweis, L., Kyriazi, Z., Pipitone, C., Piwowarczyk, J., Rabaut, M., Sørensen, T.K., van Dalfsen, J., Vassilopoulou, V., Vega Fernández, T., Vincx, M., Vöge, S., Weber, A., Wijkmark, N., Jak, R., Qiu, W., ter Hofstede, R., 2013. Monitoring and evaluation of spatially managed areas: A generic framework for implementation of ecosystem based marine management and its application. Mar. Policy 37, 149-164. doi:10.1016/j.marpol.2012.04.012

Suarez de Vivero, J.L., Rodriguez Mateos, J.C., 2012. The Spanish approach to marine spatial planning. Marine Strategy Framework Directive vs. EU Integrated Maritime Policy. Mar. Policy 36, 18-27. doi:10.1016/j.marpol.2011.03.002 
Tóth, K., Portele, KC., Illert, A., Lutz, M., Nunes de Lima, M. 2012. A conceptual model for developing interoperability specifications in spatial data infrastructures. JRC Ref Rep. doi:10.2788/20697.

TPEA 2014.Transboundary Planning in the European Atlantic: Pilot Areas Report. University of Liverpool, Liverpool, UK, 31 July 2014.

TPEA, 2014. Transboundary Planning in the European Atlantic. WWW document:http://www.msprn.net/?option=com_msprn\&view=project\&id=32 (accessed 23.05.2015).

Vanden Eede, S., Laporta, L., Deneudt, K., Stienen, E., Derous, S., Degraer, S., Vincx, M., 2014. Marine biological valuation of the shallow Belgian coastal zone: A space-use conflict example within the context of marine spatial planning. Ocean Coast. Manag. 96, 61-72. doi:10.1016/j.ocecoaman.2014.04.022

VASAB, 2001. Wismar Declaration and VASAB 2010+ Spatial Development Action Programme. Wismar: Vision and Strategies around the Baltic Sea 2010.

Wichorowski M., Fidler K., Zwierz M. and Käppeler B. 2011 Data exchange structure for Maritime Spatial Planning. "BaltSeaPlan Report no. 20" Reports-andPublications 809/1.

Zaucha, J., 2014. Sea basin maritime spatial planning: A case study of the Baltic Sea region and Poland. Mar. Policy 50, 34-45. doi:10.1016/j.marpol.2014.05.003

Zaucha, J., 2014a. The Key to Governing the Fragile Baltic Sea. Maritime Spatial Planning in the Baltic Sea Region and Way Forward. VASAB, Riga.

Zaucha, J., Conides, A., Klaoudatos, D., Norén, K., 2016. Can the ecosystem services concept help in enhancing the resilience of land-sea social-ecological systems? Ocean Coast. Manag. doi:10.1016/j.ocecoaman.2016.01.015 
Appendix I - List of keywords used for the analysis of marine/maritime content in the Inspire Geo-Portal

\begin{tabular}{|c|c|c|}
\hline Marine I Maritime Sector & $\begin{array}{c}\text { Keywords taken from the } \\
\text { list of official translated } \\
\text { values }\end{array}$ & Other keywords used \\
\hline $\begin{array}{l}\text { Land-based and marine- } \\
\text { based pollution }\end{array}$ & $\begin{array}{l}\text { Estuary pollution } \\
\text { Eutrophication } \\
\text { Liability for marine accidents } \\
\text { Litter } \\
\text { Marine pollution } \\
\text { Ocean dumping } \\
\text { Ocean outfall } \\
\text { Sea outfall } \\
\text { Ship garbage } \\
\text { Ship waste disposal } \\
\text { Shipping accident } \\
\text { Underwater outlet } \\
\text { Waste water discharge }\end{array}$ & $\begin{array}{l}\text { Contaminants + marine } \\
\text { Contaminants + sea } \\
\text { Pollution + coast } \\
\text { Pollution + sea } \\
\text { Underwater noise }\end{array}$ \\
\hline Cultural heritage & Shipwreck & $\begin{array}{l}\text { Cultural heritage + } \\
\text { underwater } \\
\text { Underwater heritage } \\
\text { Underwater + heritage }\end{array}$ \\
\hline Tourism & $\begin{array}{l}\text { Bathing } \\
\text { Beach } \\
\text { Seaside footpath } \\
\text { Marina } \\
\text { Seaside resort }\end{array}$ & Cruise \\
\hline Energy and mining & $\begin{array}{l}\text { Marine sediment } \\
\text { Offshore oil drilling } \\
\text { Offshore mining } \\
\text { Oil pollution }\end{array}$ & $\begin{array}{l}\text { Offshore + gas } \\
\text { Offshore + oil } \\
\text { Offshore + platform }\end{array}$ \\
\hline
\end{tabular}




\begin{tabular}{|c|c|c|}
\hline & $\begin{array}{l}\text { Thermal sea power } \\
\text { Tidal power } \\
\text { Sediment transport }\end{array}$ & \\
\hline Coast risk management & $\begin{array}{l}\text { Access to the sea } \\
\text { Coastal erosion } \\
\text { Land reclamation } \\
\text { Marine engineering } \\
\text { Polder } \\
\text { Sea level rise } \\
\text { Sea water protection }\end{array}$ & $\begin{array}{l}\text { Coastal floods } \\
\text { Erosion + coast } \\
\text { Erosion + sea } \\
\text { Floods + coast }\end{array}$ \\
\hline Marine regions / areas & $\begin{array}{l}\text { Black Sea } \\
\text { Intertidal zone } \\
\text { Mediterranean Sea } \\
\text { Open sea } \\
\text { Public maritime domain } \\
\text { seashore }\end{array}$ & $\begin{array}{l}\text { Contiguous zone } \\
\text { EEZ } \\
\text { High sea } \\
\text { Territorial sea }\end{array}$ \\
\hline Bathymetry & $\begin{array}{l}\text { Deep sea } \\
\text { Sea bed } \\
\text { Submarine }\end{array}$ & $\begin{array}{l}\text { Bathymetry } \\
\text { Depth + sea } \\
\text { Seabed }\end{array}$ \\
\hline $\begin{array}{l}\text { Habitats and biodiversity } \\
\text { (Ecology) }\end{array}$ & $\begin{array}{l}\text { Coastal ecosystem } \\
\text { Fish + sea } \\
\text { Fish disease } \\
\text { Marine biology } \\
\text { Marine conservation area } \\
\text { Marine ecology } \\
\text { Marine environment } \\
\text { Marine fauna } \\
\text { Marine mammal } \\
\text { Marine organism } \\
\text { Marine park } \\
\text { Marine resources } \\
\text { conservation } \\
\text { Phytoplankton } \\
\text { Protected marine zone } \\
\text { Seagrass bed }\end{array}$ & $\begin{array}{l}\text { Alien species } \\
\text { Coral } \\
\text { Food web } \\
\text { Marine habitats } \\
\text { Zooplankton }\end{array}$ \\
\hline Oceanographic features & Marine geochemistry & wave \\
\hline
\end{tabular}




\begin{tabular}{|c|c|c|}
\hline & $\begin{array}{l}\text { Marine geology } \\
\text { Marine geophysics } \\
\text { Ocean circulation } \\
\text { Ocean temperature } \\
\text { Ocean-air interface } \\
\text { Oceanic climate } \\
\text { Sea circulation } \\
\text { Sea level } \\
\text { Sea water } \\
\text { Sea wave } \\
\text { Tidal water }\end{array}$ & \\
\hline Fisheries and aquaculture & $\begin{array}{l}\text { Aquaculture }+ \text { sea } \\
\text { Coastal fishing } \\
\text { Fish farming } \\
\text { Fisheries structure } \\
\text { Fishing ground } \\
\text { Fishing license } \\
\text { Fishing vessel } \\
\text { Living marine resources } \\
\text { Marine fishery } \\
\text { National fishing reserve } \\
\text { Overfishing } \\
\text { Sea resources } \\
\text { Shellfish }\end{array}$ & $\begin{array}{l}\text { Crustacean } \\
\text { Mariculture } \\
\text { Mollusc } \\
\text { Seafood }\end{array}$ \\
\hline Maritime transport & $\begin{array}{l}\text { Ferry } \\
\text { Maritime navigation } \\
\text { Maritime transport } \\
\text { Oil recovery vessel } \\
\text { Ship } \\
\text { Shipbuilding } \\
\text { Tanker }\end{array}$ & $\begin{array}{l}\text { Ballast } \\
\text { Port }\end{array}$ \\
\hline
\end{tabular}


Appendix II - Definitions of the terminology used, included in the INSPIRE Directive (2007/2/EC)

'infrastructure for spatial information' or 'spatial data infrastructure' means metadata, spatial data sets and spatial data services; network services and technologies; agreements on sharing, access and use;

'spatial data' means any data with a direct or indirect reference to a specific location or geographical area;

'spatial data set' means an identifiable collection of spatial data;

'spatial data services' means the operations which may be performed, by invoking a computer application, on the spatial data contained in spatial data sets or on the related metadata;

'spatial object' means an abstract representation of a real-world phenomenon related to a specific location or geographical area;

'metadata' means information describing spatial data sets and spatial data services and making it possible to discover, inventory and use them;

'interoperability' means the possibility for spatial data sets to be combined, and for services to interact, without repetitive manual intervention, in such a way that the result is coherent and the added value of the data sets and services is enhanced;

'INSPIRE geo-portal' means an Internet site, or equivalent, providing access to the discovery services. 